\section{Genetic Analysis of a Cold-sensitive Chromosome Segregation Mutant of Escherichia coli $\mathrm{K} 12$}

\author{
Toshiaki Kudo,* Kazuo NaGaI** \\ and Gakuzo TAMURA \\ Department of Agricultural Chemistry, Faculty of \\ Agriculture, University of Tokyo, Tokyo \\ Received October 6, 1976
}

The cell division process of bacteria mainly consists of DNA replication, chromosome segregation and septation. Among them, the chromosome segregation process is almost unknown. Only two temperaturesensitive chromosome segregation mutants were isolated from $E$. coli. ${ }^{1,2)}$ Therefore, we isolated a cold-sensitive (cs) chromosome segregation mutant from $E$. coli K12 JE1011 and analyzed it physiologically. ${ }^{3)}$ In this note the genetic analysis of the chromosome segregation mutant, cs $2-68$, will be presented. Based on the results below, the $c s$ gene of strain $\operatorname{cs} 2-68$ has now been mapped on the chromosome at approximately $81 \mathrm{~min}$ in accordance with the designation by B. J. Bachmann, K. B. Low and A. L. Taylor.4)

Our previous results of the conjugation experiments revealed that the $c s$ gene of strain $c s 2-68$ was located between approximately $79 \mathrm{~min}$ and $90 \mathrm{~min}$ on $E$. coli genetic map. ${ }^{3,4)}$

To further examine the precise position, we tried to test the co-transduction by phage Plvir. The transduction was performed by the usual basic procedures. ${ }^{5)}$ The cold-sensitive chromosome segregation mutant, cs2-68, was used as the Pl-donor strain and the strains which had markers located in that region were used as recipients. Table I lists the strains used. Coldsensitive or cold-resistant ( $c r$ ) transductants were determined by observation of cell shape after incubation at $20^{\circ} \mathrm{C}$. As shown in Table II, the cs gene of strain $\operatorname{cs} 2-68$ was co-transducible with $p y r E$ at a frequency of 80 per cent but not with $x y l$, ilv, metE, rha or argE. We therefore concluded that the $c s$ gene of strain $\operatorname{cs} 2-68$ was located near pyrE.

As described above, Hirota already reported the isolation and the genetic analysis of two temperaturesensitive chromosome segregation mutants, par $A$ and par $B$. The par $A$ gene was located near pur $A$ and the $\operatorname{par} B$ gene was located between ser $A$ and $\operatorname{met} C$ (Fig. 1).

* Present address: The Institute of Physical and Chemical Research, Wako-shi, Saitama-ken 351.

* Present address: Department of Molecular Biology and Microbiology, Tufts University School of Medicine, Boston, Massachusetts 02111 U.S.A.
Table I. Bacterial Strains

\begin{tabular}{|c|c|c|}
\hline Strain & Properties & Source \\
\hline JE1011 & $\begin{array}{l}\mathrm{F}^{-} \text {thr leu trp his thy } \\
\text { thi ara lac gal xyl mtl } \\
\text { str-r }\end{array}$ & H. Matsuzawa \\
\hline $\operatorname{cs} 2-68$ & $\begin{array}{l}\text { cs mutant derivative of } \\
\text { JE1011 } \\
\text { thr leu trp his pro }{ }^{a)} \text { thy } \\
\text { thi ara lac gal } x y l \text { mtl } \\
\text { str-r pcsA }\end{array}$ & This paper \\
\hline AB2277sus ${ }^{-}$ & $\begin{array}{l}\mathrm{F}^{-} \text {ilv metE his trp pro } \\
\text { mtl mal ara lac gal rha } \\
\text { thi T1-r str-r }\end{array}$ & M. Yamasaki \\
\hline $\mathrm{AB} 1157$ & $\begin{array}{l}\mathrm{F}^{-} \text {argE-3 his-4 thr-1 } \\
\text { leu-6 pro } A-2 \text { ara-14 } \\
\text { galK-2 lac } Y-1 \text { xyl-5 mtl-1 } \\
\text { thi-1 tsx-33 strA-31 } \\
\text { sup-37 }\end{array}$ & N. Otsuji \\
\hline AT2243 & Hfr C pyrE met & S. Shinomiya \\
\hline
\end{tabular}

a) During mutagenesis cs2-68 acquired the auxotrophic marker pro.

Table II. Transduction Frequencies

\begin{tabular}{|c|c|c|c|}
\hline \multirow{2}{*}{ Donor } & \multirow{2}{*}{ Recipient } & \multirow{2}{*}{$\begin{array}{c}\text { Selected } \\
\text { marker }\end{array}$} & es-transductants \\
\hline & & & Total-transductants \\
\hline $\operatorname{cs} 2-68$ & $\mathrm{AB} 1157$ & $x y l$ & $0 / 52$ \\
\hline $\operatorname{cs} 2-68$ & AT2243 & pyrE & $23 / 28$ \\
\hline $\operatorname{cs} 2-68$ & AT2243 & pyrE & $\left.24 / 30^{a}\right)$ \\
\hline $\operatorname{cs} 2-68$ & $\mathrm{AB} 2277$ sus $^{-}$ & ily & $0 / 93$ \\
\hline $\operatorname{cs} 2-68$ & AB2277sus ${ }^{-}$ & metE & $0 / 39$ \\
\hline $\operatorname{cs} 2-68$ & AB2277sus ${ }^{-}$ & rha & $0 / 28$ \\
\hline $\operatorname{cs} 2-68$ & $\mathrm{AB} 1157$ & $\arg E$ & $0 / 58$ \\
\hline
\end{tabular}

Plvir phage was used. cs2-68; cs. AT2243, AB1157, AB2277sus-; cr.

a) This result was obtained from another experiment.

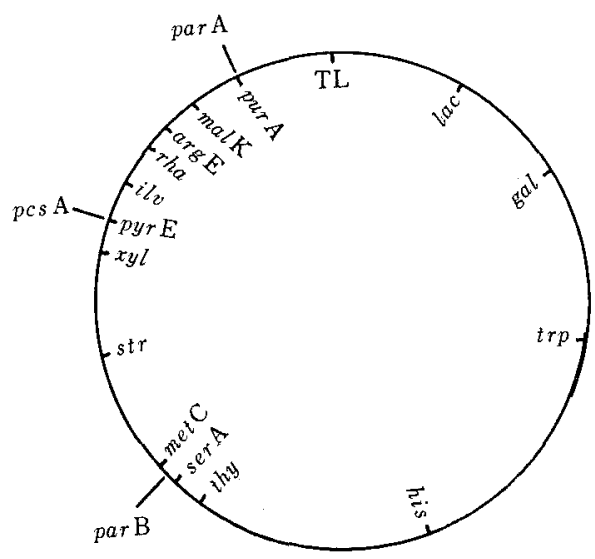

FIG. 1. Linkage Map of Escherichia coli K12. 
As indicated by the results of genetic analysis of strain cs2-68, the $c s$ gene is distinct from them and is located near pyrE. Therefore the mutated gene in this strain is designated pcs $A$ (partition $c s$ ).

Acknowledgements. We are very much indebted to M. Yamasaki, N. Otsuji, H. Matsuzawa and S. Shinomiya for their gifts of bacterial strains and Plvir phage.

\section{REFERENCES}

1) Y. Hirota and M. Ricard, In "Biology and radiobiology of anuclete systems I," Academic Press Inc., New York, 1972, p. 29.

2) Y. Hirota, Kagaku, 44, 536 (1974).

3) T. Kudo, K. Nagai and G. Tamura, Agric. Biol. Chem., 41, 89 (1977).

4) B. J. Bachmann, K. B. Low and A. L. Taylor, Bacteriol. Rev., 40, 116 (1976).

5) E, S. Lennox, Virology, 1, 190 (1955). 